\title{
PRELIMINARY MECHANICAL TEST OF PROXIMAL FEMUR REINFORCEMENT WITH CEMENTED X-SHAPED PMMA
}

\section{ENSAIO MECÂNICO PRELIMINAR DO REFORÇO FEMORAL PROXIMAL COM CIMENTO ÓSSEO EM FORMA DE "X"}

\author{
Anderson Freitas ${ }^{1}$, Welvis Soares Camargo $^{2}$, Ruben Jeri Aquino ${ }^{2}$, Vincenzo Giordano Neto ${ }^{3}$, Aluízio Fernandes Bonavides Junior ${ }^{4}$, \\ Antônio Carlos Shimano ${ }^{5}$ \\ 1. Instituto de Pesquisa e Ensino do Hospital Ortopédico e Medicina Especializada (IPE-HOME), Brasília, DF, Brazil. \\ 2. Hospital Regional do Gama (HRG), Brasília, DF, Brazil. \\ 3. Hospital Municipal Miguel Couto (HMMC), Rio de Janeiro, RJ, Brazil. \\ 4. Hospital das forças Armadas (HFA), Brasília, DF, Brazil. \\ 5. Department of Biomechanics, Medicine and Rehabilitation of the Locomotor Apparatus, Universidade de São Paulo (USP), Ribeirão Preto, SP, Brazil.
}

\section{ABSTRACT}

Objective: To evaluate the mechanical behavior of the proximal end of the femur submitted to the X-shaped polymethylmethacrylate (PMMA) reinforcement technique. Methods: Fifteen synthetic femurs, with a Nacional ${ }^{\circledR}$ density of 10 PCF, were divided into two groups: the DX group, with 5 units that were submitted to PMMA reinforcement, and the DP group, with 10 units, which were evaluated intact. The volume of PMMA required, the maximum load, and the absorbed energy to fracture were analyzed by means of a static mechanical bending test simulating a fall on the greater trochanter. Results: A mean of $6 \mathrm{ml}$ of PMMA was used to model the X-reinforcement; it was observed that the DX group presented significantly higher maximum load (median $=1553 \mathrm{~N}, \mathrm{p}=0.005$ ) and absorbed energy to fracture (median $=9.7 \mathrm{~J} ; \mathrm{p}=0.050$ ) than the DP group (median $=905 \mathrm{~N}$ and $6.6 \mathrm{~J}$ ). Conclusion: X-reinforcement of the proximal end of synthetic femurs showed a statistically significant increase in the maximum load and absorbed energy to fracture in the mechanical assay when compared to the control group. Level of Evidence III, Experimental study.

Keywords: Intertrochanteric fractures. Femur. Femoral fractures. Polymethylmethacrylate. Osteoporosis.

\section{RESUMO}

Objetivo: Avaliar o comportamento mecânico da extremidade proximal do fêmur submetido à técnica de reforço com polimetilmetacrilato (PMMA) em forma de X. Métodos: Foram utilizados 15 fêmures sintéticos, com densidade de 10 PCF da Naciona ${ }^{\circledR}$, divididos nos grupos DX, com 5 unidades submetidas ao reforço com PMMA, e DP com 10 unidades, avaliados com sua integridade intacta. Foram analisados o volume de PMMA necessário, os valores da carga máxima e a energia absorvida até a fratura por meio de ensaio mecânico estático de flexão, simulando queda sobre o trocanter maior. Resultados: Foram usados em média $6 \mathrm{ml}$ de PMMA para a modelagem do reforço em $X$ e observou-se que o grupo DX apresentou carga máxima (mediana $=1553 \mathrm{~N} ; p=0,005$ ) e energia absorvida até fratura (mediana $=$ $9,7 \mathrm{~J} ; p=0,050$ ) significativamente maior que o grupo DP (mediana $=905 \mathrm{~N}$ e 6,6 J). Conclusão: O reforço em X da extremidade proximal de fêmures sintéticos apresentou incremento estatisticamente significativo da carga máxima e energia absorvida até a fratura no ensaio mecânico em comparação com o grupo controle. Nível de evidência III, Estudo experimental.

Descritores: Fratura intertrocantérica. Fêmur. Fraturas do fêmur. Polimetilmetacrilato. Osteoporose.

Citation: Freitas A, Camargo WS, Aquino RJ, Neto VG, Bonavides Jr. AF, Shimano AC. Preliminary mechanical test of proximal femur reinforcement with cemented x-shaped pmma. Acta Ortop Bras. [online]. 2018;26(4):231-5. Available from URL: http://www.scielo.br/aob.

\section{INTRODUCTION}

Osteoporosis is a public health problem worldwide, and is more prevalent among the elderly female population. ${ }^{1}$ This disease is characterized by a reduction in bone mineral density, accompanied by a reduction in mechanical resistance of the bone. Its main factor of socioeconomic impact is the occurrence of low energy trauma fractures, and of these, fracture of the proximal femur (PF) is the one with the highest mortality rate. ${ }^{2}$
Mortality arising from fracture of the PF due to osteoporosis is as high as 30\% the first post-operative year. ${ }^{3,4}$ Patients who present fracture due to osteoporosis in this region have an increased risk of a new fracture in the same region of the contralateral hip in the two-year period following the first fracture, and this percentage can increase five years after the first episode. ${ }^{5}$

The various therapeutic resources available are aimed at avoiding or reducing fractures due to osteoporosis of the PF. They can be

All authors declare no potential conflict of interest related to this article. 
divided into nonpharmacological and pharmacological methods. ${ }^{6,7}$ The methods have significant results, with a $40 \%$ to $60 \%$ reduction in the occurrence of fractures of the PF, although there are limiting factors to their use, and complete results. These include: lack of adhesion to treatment, side effects to the medications, adverse events, and difficulty of access by a large portion of the population..$^{8,9,10}$ As a result, around $50 \%$ of the population treated for osteoporosis is vulnerable to a new fracture of the PF due to interruption of the treatment. ${ }^{10}$

Reinforcing the osteoporotic PF, with the aim of increasing mechanical resistance in this region, using a method that targets the bone tissue, is presented in the literature by experimental studies using cadaver bones. Products used for the reinforcement are: elastomers (silicone), screws, calcium phosphate cement, and polymethylmethacrylate (PMMA), the latter being the most frequently used. ${ }^{11}$ The majority of these products present favorable results in relation to properties of maximum load and absorbed energy for the occurrence of fracture of the PF. ${ }^{12-16}$ However, questions remain relating to reinforcement $P F$, such as determining the best positioning to optimize biomechanical performance, and the volume of PMMA to be used. ${ }^{17}$

The aim of this work was to evaluate the mechanical behavior of the proximal femoral head with X-shaped polymethylmethacrylate (PMMA) reinforcement, created by the author and not previously described in the literature.

\section{MATERIALS AND METHODS}

Fifteen synthetic polyurethane femurs were used for the mechanical essays, with density of 10PCF 10PCF (c-1010), obtained from Nacional ${ }^{\circledR}$. The femoral used was $330 \mathrm{~mm}$ in diameter with diaphysis length of $45 \mathrm{~mm}$. The femurs were divided into two groups; DP and DX. DP $(n=5)$ is the control group with proximal femoral head intact. DX $(n=10)$ is the group with femurs filled with PMMA in the trochanteric region and femoral neck. Next, two holes (PR) were made, denominated PR I and PR II.

Each PR of the DX group was prepared using a $220 \times 2.5 \mathrm{~mm}$ steel guidewire, a $180 \times 6 \mathrm{~mm}$ cannulated drill, and a Stryker ${ }^{\circledR}$ model $120 \mathrm{~K}$ electric motor. The holes were positioned as follows:

PR I - A point was marked on a line drawn on the longitudinal axis of the lateral surface of the synthetic model, $25 \mathrm{~mm}$ from the apex of the greater trochanter. From this point, another line was drawn, perpendicular to the first, $10 \mathrm{~mm}$ in the posterior direction, where the point of entry of the guidewire was established, (Figure 1a). The guidewire was introduced into this hole, using radioscopy, at an angle that enabled a straight line to be drawn through the two principal points - one in the central region of the middle third of the femoral neck and the other in the inferior anterior portion of the femoral head. (Figure 2a, b) Once the guidewire had been positioned, and its correct placement verified in the frontal and axial views, a $6 \mathrm{~mm}$ cannulated drill was used to create the PR 1 perforation.

PR II - At the entry point of the PR 1, a line was drawn parallel to the longitudinal axis of the lateral surface of the synthetic model, and as this line passed the apex of the greater trochanter, the point of entry of the PR II was determined. (Figure 1b) in the same plane of PR I, at an angle that enabled a straight line to be drawn between two principal points - the upper transition of the neck of the greater trochanter and PR I, crossing it. (Figure 3a, b) Having determined the correct positioning in the frontal and axial views, using radioscopy, this position was used as a guide to create the hole, using a $6 \mathrm{~mm}$ diameter cannulated drill.

After preparing the holes in the DX group, the PR I and II holes were filled in, model by model, with a unit of PMMA from the same

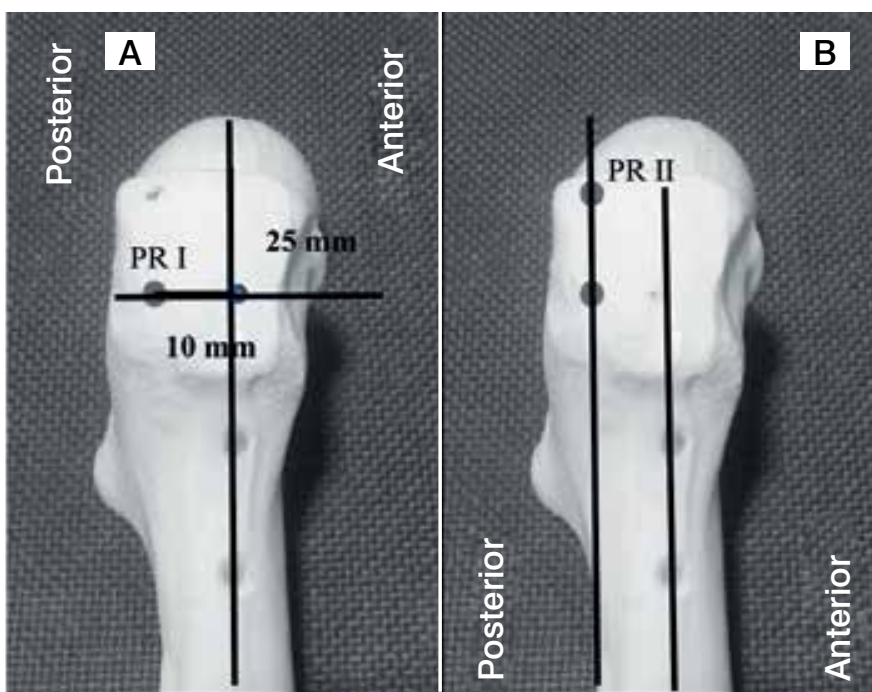

Figure 1. Images illustrating the locations and parameters of the entry points of PR I and PR II.

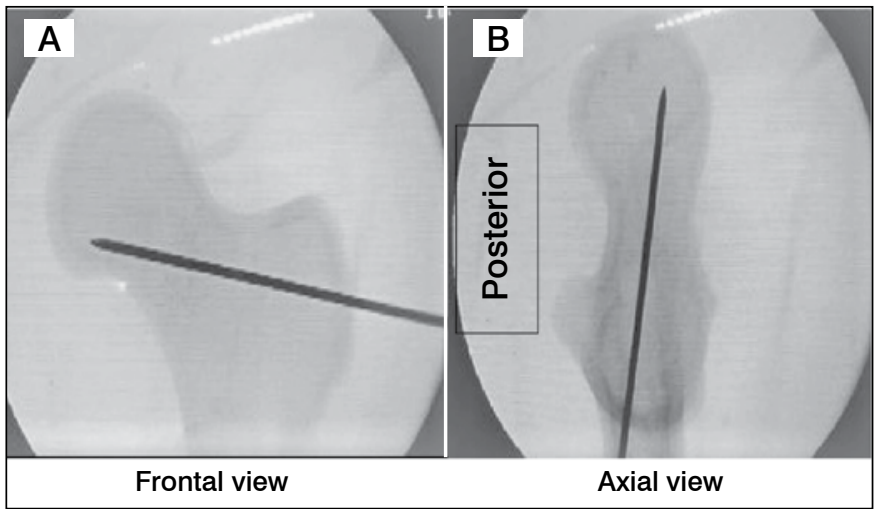

Figure 2. Radioscopic images and positioning of the guidewire, at their points of references for the preparation of PR I.

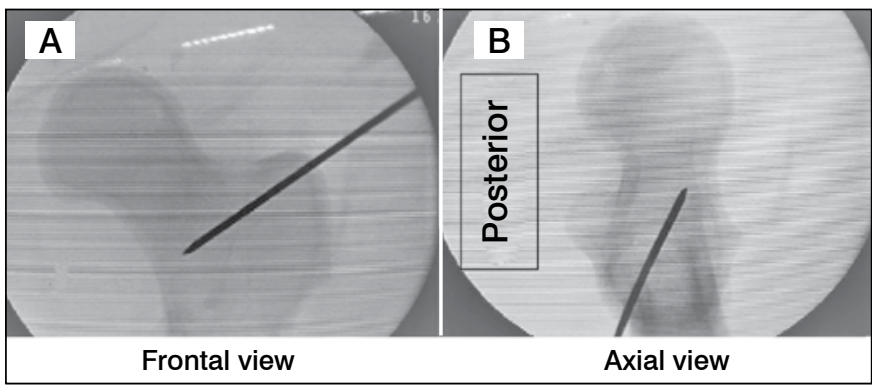

Figure 3. Radioscopic images of the positioning of the guidewire, at its points of reference, for the preparation of PR II.

manufacturer, of the Simplex $\mathrm{P}^{\circledR}$ brand, with the concentration and volume presented in its commercial kit. These were mixed manually to form a homogenous liquid, and transferred to a $20 \mathrm{ml}$ syringe. Injection of the liquid into holes was anterograde, and complete filling was observed during the procedure using radioscopy. (Figure 4 a.b). The average volume of PMMA used was observed, and calculated by numbering the syringes and recording the amount used. For the mechanical assays, an MTS ${ }^{\circledR}$ ("Materials Testing System") machine, model 810 - FlexTest 40 was used, from the laboratory of mechanical assays - Department of engineering and materials 
manufacture - UNICAMP- SP. The assayed femur was fixed in an assay device with screws and a metallic support, leaving $150 \mathrm{~mm}$ of its length outside the fixation point. The device with the femur was then positioned at the base of the assay machine, tilted $10^{\circ}$, with horizontal and internal rotation of $15^{\circ}$, with the greater trochanter supported on a silicone disk of $30.5 \mathrm{~mm}$ in diameter, to simulate a fall onto the trochanter. (Figures $5 \mathrm{a}, \mathrm{b}$ ) A load cell with $10 \mathrm{k} / \mathrm{N}$ capacity was used, with a pre-load of $40 \mathrm{~N}$ and load application speed of $2 \mathrm{~mm} / \mathrm{s}$. the force was applied to the head of the femur until fracture of the assayed region. The mechanical properties evaluated were: maximum load and absorbed energy.

The results of the mechanical properties are presented in the form of tables and graphs. The data in the graphs were expressed as central and dispersion measurements, to illustrate the differences between groups. The Shapiro-Wilk test was conducted to verify the normality of the data. Next, inferential analysis was conducted using the Mann-Whitney test, to compare the properties of maximum load and absorbed energy until fracture between the groups. A level of significance of $5 \%$ was adopted. The statistical analysis was processed using the statistical software program SAS ${ }^{\circledR}$ System, version 6.11 (SAS Institute, Inc., Cary, North Carolina).

\section{RESULTS}

The mean PMMA used to fill each unit of the DX group was $6 \mathrm{ml}$. The synthetic models of both groups presented fracture of the femoral neck in the basicervical region. (Figure 6)

The mean maximum load obtained in the DP group was $935 \mathrm{~N}$, with standard deviation of $290 \mathrm{~N}$. In this DX group, this figure was $1500 \mathrm{~N}$, with standard deviation of $180 \mathrm{~N}$.

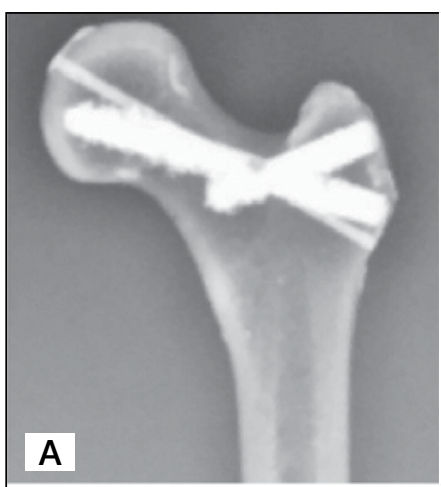

Frontal view

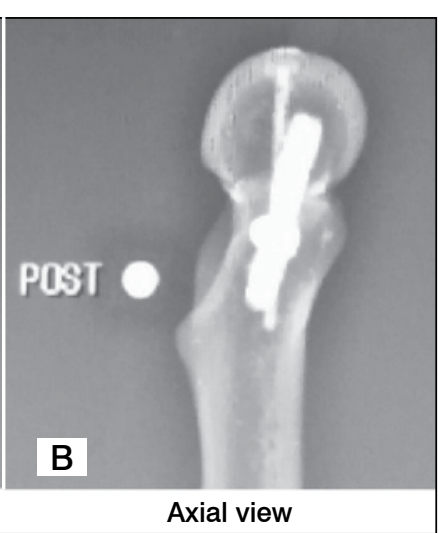

Axial view
Figure 4. Radiographic images of the synthetic model after completely filling the holes.

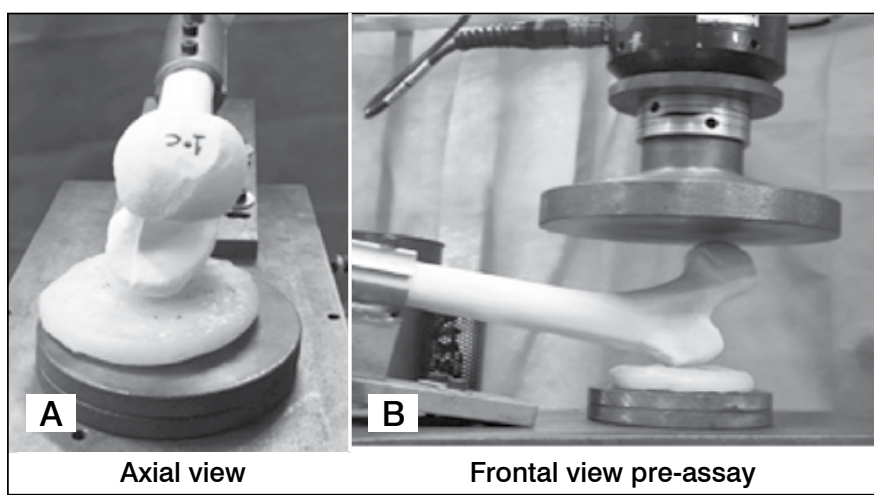

Figure 5. Sample of the control group, fixed onto the machine, demonstrating its positioning. At the mechanical pre-assay moment.
The energy absorption values in Joules $(\mathrm{J})$ for the occurrence of fracture in the DP and DX groups were $7.0 \mathrm{~J}$ and $9.7 \mathrm{~J}$, respectively. The differences in percentage values obtained in the increases evaluated, in the maximum load and absorbed energy, showed increases of $37.6 \%$ and $26.8 \%$ between the DP and DX groups, respectively.

The general description of maximum load and energy to fracture by group (DX, DP), and the corresponding descriptive levels ( $p$ valor) of the Mann-Whitney test, are shown in table 1.

It was observed that the DX group presented significantly greater maximum load (mean $=1500 \mathrm{~N} ; p=0.005$ ) and energy to fracture (mean $=9.7 \mathrm{~J} ; p=0.050$ ) than the SD group (mean $=935 \mathrm{~N}$ and 7.1J), as illustrated by Figures 7 and 8, respectively.

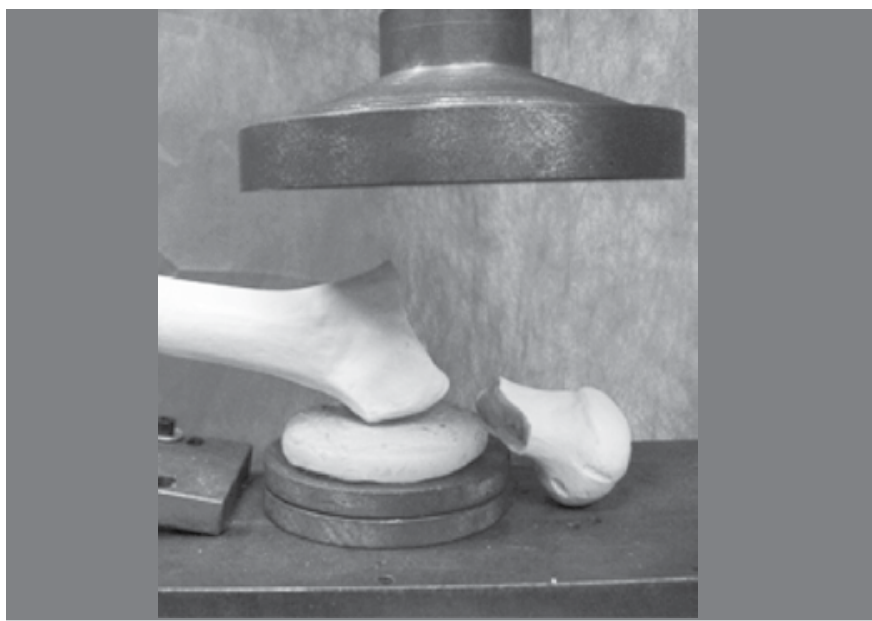

Figure 6. Sample of the DX group post-assay, showing the fracture of the femoral neck in the basicervical region.

Table 1. Description of maximum load and energy to fracture, by group.

\begin{tabular}{|c|c|c|c|c|c|c|c|c|}
\hline Variable & $\mathbf{n}$ & mean & SD & median & IQR & minimum & maximum & $p$ value \\
\hline \multicolumn{9}{|c|}{ Maximum Load (N) } \\
\hline DX & 5 & 1500 & 180 & 1553 & $1367-1607$ & 1182 & 1627 & \multirow{2}{*}{0.005} \\
\hline $\mathrm{DP}$ & 10 & 935 & 290 & 905 & $704-1174$ & 555 & 1399 & \\
\hline \multicolumn{9}{|c|}{ Energy to fracture $(\mathrm{J})$} \\
\hline DX & 5 & 9.7 & 1.4 & 9.7 & $8.4-11.1$ & 8.1 & 11.5 & \multirow{2}{*}{0.050} \\
\hline DP & 10 & 7.1 & 2.5 & 6.6 & $4.6-9.7$ & 4.4 & 10.4 & \\
\hline
\end{tabular}

SD: Standard deviation; IQR: interquartile range (Q1-Q3). Mann-Whitney test.

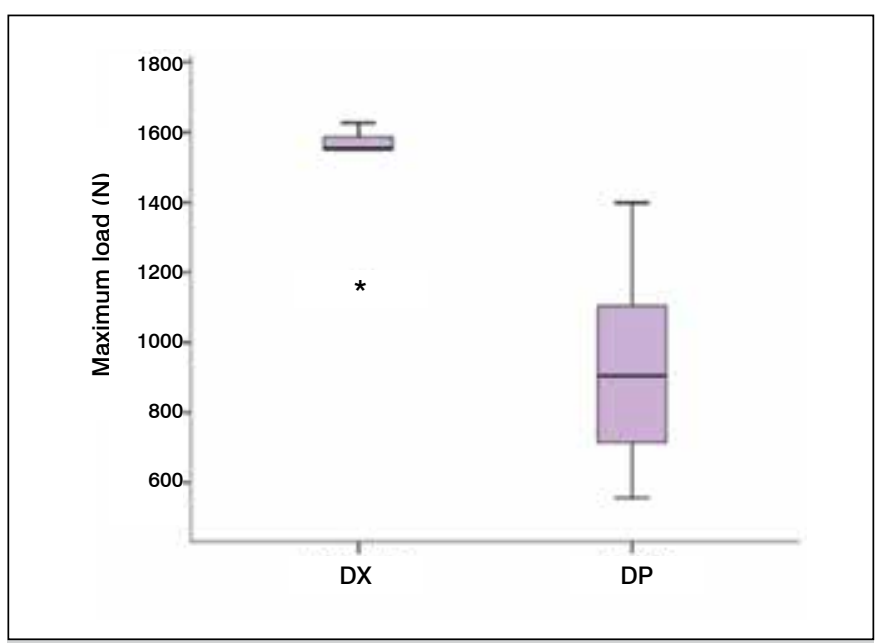

Figure 7. Maximum load by group $(p=0.005)$ 


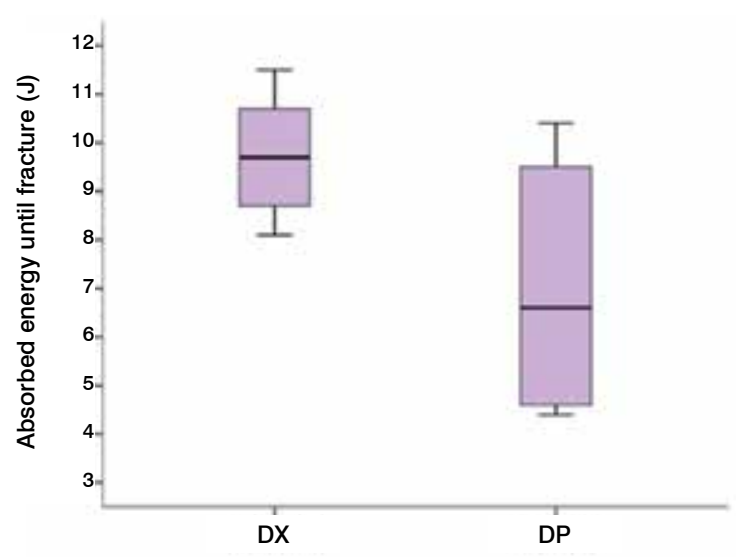

Figure 8. Energy to fracture, by group $(p=0.05)$

\section{DISCUSSION}

The fracture mechanism of the PF with fall on the trochanter has its own characteristics, as this positioning of the trauma inverts the mechanical attributions of the structures in this region. The areas that are generally exposed to compression forces are also exposed to traction forces, and vice versa, making this segment, when associated with the bone fragility, susceptible to fractures by minimum trauma fractures, and hindering the search for information on the best positioning of the bone reinforcement with PMMA in this region. ${ }^{17}$ Another difficulty in determining a positioning of excellence in the reinforcement of the PF is the biomechanical complexity of the proximal femur, as well as the inversions of load attributions in this trauma mechanism. No reports were found in the literature describing techniques to study the creation of other holes in different regions of the PF, and in particular, to study the greater trochanter, which carries great mechanical responsibility in the fracture mechanism and dissipation of energy of the trauma. ${ }^{13,18}$

The mean volume of PMMA used to fill each model in the DX group $(6.0 \mathrm{ml})$, which is lower than in cases described in the literature, which range from 9.5 to $40.0 \mathrm{ml}$ of PMMA used. ${ }^{12-16}$ This fact is of great importance, as reducing the volume of PMMA will also reduce possible damage to the region by the thermal action caused by the PMMA polymerization process, since the higher the volume of PMMA used, the greater the heat given off at the site.
The choice and use of the synthetic model from same material and batch helps to standardize the mechanical assays, seeking to reduce the variables relating to cadaver models, such as: diameter of the femoral neck, neck angle, variations in thickness of the cortical components, and variations in bone densities, all of which can affect the results. ${ }^{18,19}$ However, the composition of the DP group was fundamental, as this enabled a comparative parameter. It should also be emphasized that this group presented a relatively high standard deviation. For this reason, 10 models were assayed to enable it to be reduced, a fact that did not occur in the DX group. The absolute values for maximum load and absorbed energy obtained in this study cannot be compared to the results found in the literature, as the mechanical properties of the model are far beyond those of the cadaver models commonly seen in previous publications. However, the differences obtained in these maximum load and energy tests were $37.6 \%$ and $26.8 \%$ respectively, between the groups analyzed. The values as percentages, of the assay described in the literature, using the lower mean in volume of PMMA $(9.5 \mathrm{ml})$ obtained an increase of $30 \%$ in maximum load and $46 \%$ in energy value, ${ }^{13}$ leading us to believe that we may have equivalent or better results to those previously described, using an even lower volume of PMMA, ad using synthetic models that simulate human bones with osteoporosis, and their biomechanical properties.

The challenges related to the technique for reinforcing the PF aimed at reducing the risk of fracture in this region by minimum trauma go beyond the biomechanical structures, and certainly include complex ethical and social evaluations for their application in vivo, since implementing a surgical procedure as a prophylactic option for PF fractures can and should be something that is properly explored, as there are literal descriptions of products with this objective, and bibliographic descriptions that describe local femoral reinforcement as extremely acceptable, through the minimally invasive procedure, with little aggression for the patient at imminent risk of fracture in the non-fractured hip during surgery to treat a fractured hip, since the patient is already under anesthetic, and the bone fragility is stabilized. ${ }^{20}$ Thus, further research is needed on the subject, to add more information to our knowledge and thereby contribute to optimizing the technique of PF using PMMA, with the lowest risk.

\section{CONCLUSION}

X-shaped reinforcement of the proximal end of synthetic femurs with PMMA increased the maximum load and absorbed energy in the mechanical assays performed.

AUTHORS' CONTRIBUTIONS: Each author made significant individual contributions to this manuscript. AF $(0000-0001-6555-8193)^{\star}$ and WSC $(0000-0003-$ 3949-5859)* were the main contributors to the literature review and writing of the manuscript. RJA (0000-0003-1507-3571), ${ }^{*}$ VGN (0000-0002-4429-312X), AFBJ (0000-0003-1148-8454) ${ }^{*}$ and AF prepared the methodology and test bodies, accompanied the assays, and gathered data from the mechanical assays. AF and ACS (0000-0002-3119-2362) evaluated the data from the statistical analysis and reviewed the manuscript VGN, AFBJ and ACS also contributed to the intellectual concept of the study. *ORCID (Open Researcher and Contributor ID).

\section{REFERENCES}

1. Szule P, Bouxsein ML. Part I Overview of osteoporosis: epidemiology and clinical management. In: Vertebral fracture initiative. International Osteoporosis Foundation. 2011.

2. Assessment of fracture risk and its application to screening for postmenopausal osteoporosis. Report of a WHO study group. World Health Organ Tech Rep Ser. 1994;843:1-129.

3. Hernlund E, Svedbom A, Ivergard M, Compston J, Cooper C, Stenmark J, et al. Osteoporosis in the European Union: medical management, epidemiology and economic burden. A report prepared in collaboration with the Internacional
Osteoporosis Foundation (IOF) and the European Federation of Pharmaceutical Industry Associations (EFPIA). Arch Osteoporos. 2013;8:136.

4. Ryg J, Rejnmark L, Overgaard S, Brixen K, Vestergaard P. Hip fracture patients at risk of second hip fracture: a nationwide population-based cohort study of 169, 145 cases during 1977-2001. J Boner Miner Res. 2009;24(7):1299-307.

5. Kanis JA, McCloskey EV, Johansson H, Cooper C, Rizzoli R, Reginster JY. European guidance for the diagnosis and management of osteoporosis in postmenopausal women. Osteoporos Int. 2013;24(1):23-57. 
6. MacLean C, Newberry S, Maglione M, McMahon M, Ranganath V, Suttorp M, et al. Systematic review: comparative effectiveness of treatments to prevent fractures in men and women with low bone density or osteoporosis. Ann Intern Med. 2008;148(3):197-213

7. Kanis JA, Cooper C, Rizzoli R, Abrahamsen B, Al-Daghri NM, Brandi ML, et al. Identification and management of patients at increased risk of osteoporotic fracture: outcomes of an ESCEO expert consensus meeting. Osteoporos Int. 2017;28(7):2023-34

8. Muchmore DB. Raloxifene: a selective estrogen receptor modulator (SERM) with multiple target system effects. Oncologist. 2000;5(5):388-92.

9. Paula FJA, Rosen CJ. Developing drugs to treat osteoporosis: lessons learned? J Clin Endocrinol Metab. 2009;94(7):2284-9.

10. Canalis E, Giustina A, Bilezikian JP. Mechanisms of anabolic therapies for osteoporosis. N Engl J Med. 2007;357(9):905-16.

11. Freitas A, Neri G, de Macedo Neto SL, Borges JLC, de Paula AP. Can be the cement augmentation an improvement method of preventing hip fractures in osteoporotic patients? Geriatr Gerontol Aging (Impr.). 2017;11(1):42-7.

12. Basafa E, Armand M. Subject-specific planning of femoroplasty: A combined evolutionary optimization and particle diffusion model approach. J Biomech. 2014;47(10):2237-43.

13. Basafa E, Murphy RJ, Otake Y, Kutzer MD, Belkoff SM, Mears SC, et al. Subject-specific planning of femoroplasty: an experimental verification study. $J$ Biomech. 2015;48(1):59-64.

14. Beckmann J, Ferquson SJ, Gebauer M, Luering C, Gasser B, Heini P
Femoroplasty-augmentation of the proximal femur with a composite bone cement-feasibility, biomechanical properties and osteosynthesis potential. Med Eng Phys. 2007;29(7):755-64.

15. Beckmann J, Springorum R, Vettorazzi E, Bachmeier S, Lüring C, Tingart M, et al. Fracture prevention by femoroplasty-cement augmentation of the proximal femur. J Orthop Res. 2011;29(11):1753-8.

16. Fliri L, Sermon A, Wähnert D, Schmoelz W, Blauth M, Windolf M. Limited $\mathrm{V}$-shaped cement augmentation of the proximal femur to prevent secondary hip fractures. J Biomater Appl. 2013;28(1):136-43.

17. Varga P, Inzana JA, Schwuedrzik J, Zysset PK, Gueorquiev B, Blauth M, et al. New approaches for cement-based prophylactic augmentation of the osteoporotic proximal femur provide enhanced reinforcement as predicted by non-linear finite element simulations. Clin Biomech. 2017;44:7-13.

18. Bakker PM, Manske SL, Ebacher V, Oxland TR, Cripton PA, Guy P. Du ring sideways falls proximal femur fracture initiate in the superolatera cortex: evidence from high-speed video of simulated fracture. J Biomech. 2009;42(12): 1917-25.

19. Papini M, Zdero R, Schemitsch EH, Zalzal P. The biomechanics of human femurs in axial and torsional loading: comparison of finite element analysis, human cadaveric femurs, and synthetic femurs. J Biomech Eng. 2007;129(1):12-9.

20. Cornelis FH, Tselikas L, Carteret T, Lapuyade B, De Baere T, Le Huec JC, et al. Percutaneous internal fixation with Y-STRUT ${ }^{\circledR}$ device to prevent both osteoporotic and pathological hip fractures: a prospective pilot study. J Orthop Surg Res. 2017;12:27. 